\title{
SAFETY AND EFFICACY AFTER SwITCH TO A SAQUinAVIR-CONTAINING Antiretroviral Regimen in Protease Inhibitor Pretreated HIV-Positive Patients
}

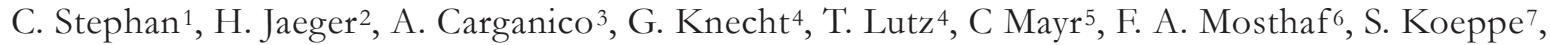 \\ M. Mueller ${ }^{8}$, E. Wolf 9 , A. Tappe ${ }^{10}$, E. Wellmann ${ }^{10}$, H. Knechten ${ }^{11}$

\begin{abstract}
${ }^{1}$ Klinikum der Johann-Wolfgang-Goethe-Universität, Frankfurt, Germany; ${ }^{2}$ MVZ Karlsplatz, HIV Research and Clinical Care Centre, Munich, Germany; ${ }^{3}$ Praxis Dres. S. Dupke / A. Carganico / A. Baumgarten, Berlin, Germany; ${ }^{4}$ Infektiologikum Frankfurt, Frankfurt, Germany; ${ }^{5}$ MVZ-Aerzteforum Seestrasse, Berlin, Germany; ${ }^{6}$ Praxis Dres. F. A. Mosthaf / M. Procaccianti / K. Zutavern-Bechtold, Karlsruhe, Germany; ${ }^{7}$ Praxis Dres. S. Koeppe / P. Kreckel, Berlin, Germany; ${ }^{8}$ Praxis Dres. B. Frietsch / A. Ulmer / M. Mueller, Stuttgart, Germany; ${ }^{9}$ MUC Research, Munich, Germany; ${ }^{10}$ Roche Pharma AG, Grenzach-Wyhlen, Germany; ${ }^{11}$ Praxenzentrum
\end{abstract} \\ Blondelstrasse (PZB), Aachen, Germany
}

\begin{abstract}
Objective: The RAINBOW survey is a multinational observational study assessing the tolerability and efficacy of ritonavir-boosted saquinavir $(\mathrm{SQV} / \mathrm{r})$, using the $500 \mathrm{mg}$ film-coated SQV formulation, in routine clinical practice. This analysis presents data from the German subgroup of protease inhibitor (PI)-pretreated, but SQV-naïve patients.

Methods: Multicenter, prospective, open-label, 48 week cohort study. Efficacy assessments included the proportion of patients with HIV-1 RNA $<50$ and $<400$ copies/mL and changes in CD4 cell count from baseline to week 48. Tolerability assessments included changes in liver enzymes and lipid levels from baseline to week 48.
\end{abstract}

Results: A total of 426 patients were included in the analysis. The proportion of patients with HIV RNA levels $<50$ copies $/ \mathrm{mL}$ at week 48 was $60.3 \%$ (compared with $31.7 \%$ at switch to SQV/r) (intent-to-treat, last observation carried forward analysis). After 48 weeks, median CD4 count increased by +61 cells $/ \mathrm{mm}^{3}$ from baseline $(\mathrm{p}<0.01)$ and $60.3 \%$ of $\mathrm{pa}-$ tients achieved HIV-1 RNA $<50$ copies/mL. Median changes in fasting triglyceride levels (stratified according to baseline level) at week 48 were: $+14 \mathrm{mg} / \mathrm{dL}$ (IQR -8; 57) for patients with baseline triglyceride $<200 \mathrm{mg} / \mathrm{dL}$; $-50 \mathrm{mg} / \mathrm{dL}$ (IQR -139; 0) for baseline triglyceride $200-750 \mathrm{mg} / \mathrm{dL}$, and $-656 \mathrm{mg} / \mathrm{dL}$ (IQR 1024; 0) for baseline triglyceride $>750 \mathrm{mg} / \mathrm{dL}(\mathrm{p}<0.01$ for all). Median changes in fasting total cholesterol (TC) levels (stratified according to baseline) were +16 $\mathrm{mg} / \mathrm{dL}(\mathrm{IQR}-3$; 43) for patients with baseline TC $<200 \mathrm{mg} / \mathrm{dL}(\mathrm{p}<0.01),-3 \mathrm{mg} / \mathrm{dL}(\mathrm{IQR}-25 ; 25)$ for baseline TC $200-300 \mathrm{mg} / \mathrm{dL}(\mathrm{p}=0.4)$, and $-47 \mathrm{mg} / \mathrm{dL}$ (IQR -87; -4) for baseline TC $>300 \mathrm{mg} / \mathrm{dL}(\mathrm{p}<0.01)$. No significant changes in liver enzymes or bilirubin were observed. SQV treatment was discontinued in $22 \%$ of patients, $6 \%$ due to side effects.

Conclusions: These data confirm the efficacy and tolerability of $\mathrm{SQV} / \mathrm{r}$ in PI-experienced, SQV-naïve patients treated in a real-life clinical setting. Of particular relevance are the improvements in triglycerides and TC levels observed in patients with baseline grade IIIIV elevations.

Key words: HIV; protease inhibitor; saquinavir; cholesterol; triglycerides

\section{INTRODUCTION}

The development of metabolic alterations such as dyslipidemia and body fat changes (lipodystrophy) is a major consideration with the use of protease inhibitors (PIs) as part of Highly Active Anti-Retroviral Therapy (HAART) [1]. The link between HAART and increased risk of cardiovascular disease was confirmed almost a decade ago [2], and increased exposure to PIs in particular has been associated with an increased risk of myocardial infarction, which is partly explained by dyslipidemia [3]. Treatment with PIs is associated with significantly increased levels of triglycerides, total cholesterol (TC), low-density lipoproteins (LDL) and high-density lipoproteins (HDL), as well as changes in body fat [4]. Lipid alterations and morphologic abnormalities vary between the different PIs; for example, indinavir has been associated with insulin resistance [5], and ritonavir-boosted lopinavir with hypertriglyceridemia and hypercholesterolemia [6], whereas atazanavir has been reported to have a relatively favorable lipid profile [7]. There are also differences in the reported efficacy and tolerability of PIs and therefore selecting and switching treatment regimens in those patients with virological failure, toxicity, or changes in lipid profiles related to a particular PI represents an important management issue.

Saquinavir (Invirase ${ }^{\circledR}, \mathrm{SQV}$ ) is a potent inhibitor of HIV-1 viral protease, which, when co-administered with ritonavir boosting $(\mathrm{SQV} / \mathrm{r}$ ) has been shown to be effective in clinical trials of treatment-naïve and treatment-experienced patients and to be associated with a more favorable lipid profile than ritonavir-boosted lopinavir and indinavir, with improved tolerability [8- 
11]. Ritonavir-boosted SQV is currently recommended for initial PI-based ART by international HIV treatment guidelines [12-15]. Initially available as $200 \mathrm{mg}$ hard capsules, SQV is now available as a $500 \mathrm{mg}$ filmcoated tablet formulation which achieves the current recommended daily dose $(1000 \mathrm{mg}$ twice daily with $100 \mathrm{mg}$ ritonavir twice daily [16]) with a reduced pill burden and simplified dosing [17]. Although there is currently wide treatment experience with various $\mathrm{SQV} /$ ritonavir combinations and with the previous SQV formulations, available data on the $500 \mathrm{mg}$ filmcoated tablets is yet limited.

The international RAINBOW survey was designed to identify a cohort of HIV-1 infected patients who initiated treatment with, $500 \mathrm{mg}$ film-coated SQVtablet in routine clinical practice. The survey aimed to include a wide cross-section of patient populations, including ART-naïve patients and ART-experienced patients with a range of pretreatment histories. In this analysis we present the final 48-week efficacy and tolerability data from patients who were previously treated with one or more PIs (PI-experienced), but who were SQV- naïve, from the German RAINBOW COHORT.

\section{Materials AND Methods}

\section{DESIGN}

The RAINBOW COHORT was a multicenter, prospective, non-interventional 48 week observational study in HIV-patients treated with SQV $500 \mathrm{mg}$ filmcoated tablets as part of their antiretroviral regimen and took place between July 2005 and May 2008.

Inclusion criteria for RAINBOW were documented HIV-1 infection and initiation of treatment with $\mathrm{SQV} /$ ritonavir (SQV/r) utilizing the $500 \mathrm{mg}$ filmcoated SQV tablet, in combination with other antiretrovirals as part of routine antiretroviral therapy (ART)

Patient selection for SQV-based antiretroviral treatment was at the discretion of the treating physician, and the decision was made in accordance with the declaration of Helsinki and with German treatment guidelines, published by the German AIDS-society [15]. Patients were included in the RAINBOW COHORT if they had been previously treated with PI containing regimens, but that did not include SQV. There were no specified exclusion criteria, and no restrictions on the use of concomitant medication. In order to avoid selection bias, all investigators were encouraged to report data from all eligible patients at their site rather than reporting on a random subset only. For patients who discontinued SQV/r treatment or with missing data, the last recorded values were carried forward for inclusion in the final analysis (up to week 48).

The following demographic/baseline characteristic data were collected: date of birth; ethnicity; gender; height; weight; previous diseases; HIV risk exposure; year of diagnosis; presumed mode of infection; current disease stage; HIV-RNA viral load and CD4+ cell count prior to starting boosted SQV treatment; antiretroviral drug history; concomitant medications, including any lipid lowering and antidiarrhetic medica- tions; and hematology and biochemistry laboratory results, including blood where available.

Efficacy and tolerability data were collected from the patient records and recorded on a central database using identifying numbers only. Patient visits were allocated to applicable windows: week 2-6, week 8-16, week 20-28, week 32-40, and week 44-52. The following data were recorded from the patient charts: CD4+ cell count; HIV-RNA viral load; date of HIVRNA viral load and CD4+ cell count; HIV-RNA assay used; lower limit of HIV-RNA assay used; weight; changes in background antiretroviral drugs; changes to/introduction of lipid lowering medications, antidiarrhetic medication and other concomitant medication; unexpected clinical adverse events; treatment adherence information and reason of premature withdrawal; hematology and biochemistry laboratory results (including fasting blood lipids).

\section{ENDPOINTS}

Tolerability endpoints were: changes in fasting lipids levels (total cholesterol [TC], high-density lipoprotein [HDL] and low-density lipoprotein [LDL] cholesterol, and triglycerides) from baseline to week 48 stratified according to baseline levels; changes in liver enzymes (alanine aminotransferase [ALT], aspartame aminotransferase [AST], and gamma glutamyl transferase [GGT]); and frequency of Grade 3 and 4 adverse events or death, including those considered by the treating physician to be related to SQV.

Efficacy endpoints were: percentage of patients with HIV-RNA $<50$ copies/mL at week 48; percentage of patients with HIV-RNA $<400$ copies/mL at week 48 ; and change in CD4 cell count from baseline at week 48 .

\section{STATISTICS}

All PI-experienced, SQV-naïve patients included in the RAINBOW COHORT with complete baseline visit were included in the analysis. Reflecting the observational nature of the study, we used an intent-to-treat (ITT) analysis of last observation carried forward (LOCF) i.e. missing values for HIV-RNA and CD4+ cell count values, lipids and liver enzymes were taken as the previous observed value.

Descriptive summary statistics were used for this cohort analysis, characterizing changes in CD4+ cell count and HIV-RNA from baseline, the type and frequency of adverse events observed, and changes in safety relevant laboratory parameters. For continuous variables the following statistics were calculated: mean; standard deviation, median, inter-quartile range (IQR) and minimum and maximum values. For categorical variables, number of values in each category and percentage of the values with regard to number of patients in the study population were calculated. Explorative statistical methods were used with regard to the efficacy endpoints and changes in safety-relevant laboratory parameters. Changes from baseline were tested for significance using the Wilcoxon signed rank test. Shifts in ranking of baseline values and week 48 values were assessed using Shift tables and McNemar/Bowker tests. 


\section{RESULTS}

Between July 2005 and February 2007, 1,669 patients overall were enrolled in the German RAINBOW COHORT. Baseline data were missing for 120 patients, leaving 1,549 patients from 66 centers with evaluable data. Of these, 669 patients received SQV as part of their antiretroviral regimen before switching to the SQV $500 \mathrm{mg}$ film-coated tablet and so were excluded from the current analysis. The remaining 880 patients were SQV-naïve. Of these, 454 patients were PI-naïve and were not included in the current analysis. In all, 426 patients were PI-experienced but SQV-naïve and met the criteria for evaluation in this analysis. Baseline characteristics and demographics of these patients are shown in Table 1.

Table 1. Baseline characteristics and demographics. MSM: Men who have sex with men; CDC: Center for Disease Control; IQR: Interquartile range; ART: Antiretroviral therapy; PI: Protease inhibitor.

\begin{tabular}{|c|c|}
\hline PI-experienced, but SQV-naïve patients & $\mathrm{n}=426$ \\
\hline Male, $\%(\mathrm{n})$ & $84(359)$ \\
\hline Age in years, median (IQR) & $43(37 ; 49)$ \\
\hline Height in $\mathrm{cm}$, median, (IQR) & $177(172 ; 182)$ \\
\hline Weight in kg, median (IQR) & $72(65 ; 80)$ \\
\hline Hepatitis B, \% (n) & $5(21)$ \\
\hline Hepatitis C, \% (n) & $12(50)$ \\
\hline \multicolumn{2}{|l|}{ Infection mode, $\%$} \\
\hline MSM & 62 \\
\hline Heterosexual & 15 \\
\hline IVDU & 7 \\
\hline Not specified & 16 \\
\hline \multicolumn{2}{|l|}{ Race, $\%$} \\
\hline Caucasian & 84 \\
\hline African & 8 \\
\hline Asian & 3 \\
\hline Not specified & 5 \\
\hline \multicolumn{2}{|l|}{ CDC stage, $\%$} \\
\hline A & 17 \\
\hline B & 43 \\
\hline $\mathrm{C}$ & 38 \\
\hline Not specified & 2 \\
\hline $\begin{array}{l}\text { Time since first diagnosis in years, median } \\
\text { (IQR) }\end{array}$ & $9(4 ; 14)$ \\
\hline $\begin{array}{l}\text { Time since first ART in years, median } \\
\text { (IQR) }\end{array}$ & $7.3(3.4 ; 9.4)$ \\
\hline $\begin{array}{l}\text { Number of previous regimen, median } \\
\text { (IQR) }\end{array}$ & $4(3 ; \geq 6)$ \\
\hline Number of previous PIs, median (IQR) & $2(1 ; 3)$ \\
\hline $\begin{array}{l}\text { Treatment interruption before start of } \\
\text { new regimen, } \%(\mathrm{n})\end{array}$ & $21(91)$ \\
\hline $\begin{array}{l}\text { Duration of treatment interruption in } \\
\text { months, median (IQR) }\end{array}$ & $8.8(3 ; 23)$ \\
\hline HIV RNA (copies/mL), median (IQR) & $599(<50 ; 31,291)$ \\
\hline $\begin{array}{l}\text { Proportion of patients with HIV RNA } \\
<50 \text { copies } / \mathrm{mL} \text { at baseline }\end{array}$ & $31.7 \%$ \\
\hline CD4-count (cells $\left./ \mathrm{mm}^{3}\right)$ median (IQR) & $320(177 ; 506)$ \\
\hline
\end{tabular}

The majority of patients was male, Caucasian, with a median age of 43 years and men who reported sex with men (MSM) as primary risk of HIV transmission. The median number of previous ART regimens was 4 , and patients had been treated with a median of 2 PIs. Details of previous ART regimens are shown in Table 2.

Table 2. Previous antiretroviral regimen. NRTI: nucleoside reverse transcriptase inhibitor; NNRTI: non-nucleoside reverse transcriptase inhibitors; PI: protease inhibitor; LPV: lopinavir; ATV: atazanavir; FAP: fosamprenavir; r: ritonavirboosted.

\begin{tabular}{|c|c|c|}
\hline Regimen & $\mathbf{n}$ & $\%$ \\
\hline$\geq 3$ NRTI & 47 & 11 \\
\hline NNRTI + NRTI & 61 & 14 \\
\hline PI/r + NRTI/NNRTI & 236 & 55 \\
\hline $\mathrm{LPV} / \mathrm{r}$ & 111 & 2 \\
\hline $\mathrm{ATV} / \mathrm{r}$ & 51 & 1 \\
\hline $\mathrm{FAP} / \mathrm{r}$ & 34 & \\
\hline Double PI & 23 & 5 \\
\hline $\mathrm{LPV} / \mathrm{ATV} / \mathrm{r}$ & 11 & \\
\hline $\mathrm{LPV} / \mathrm{FAP} / \mathrm{r}$ & 5 & \\
\hline Not specified & 46 & 11 \\
\hline Other & 13 & 3 \\
\hline
\end{tabular}

The most commonly previously used ART regimen was a PI in combination with NRTI/NNRTI (55\%) and the PI most commonly used in previous regimens was lopinavir/ritonavir (LPV/r) in $30 \%$ of patients. Of all, the main reason to switch to $S Q V / r$ was virological failure ( $\mathrm{n}=182$ patients or $42.7 \%$ ), followed by previous antiretroviral regimen intolerance $(\mathrm{n}=91 \mathrm{pa}-$

Table 3. Antiviral drugs included in SQV/ritonavir regimens NRTI: nucleoside reverse transcriptase inhibitor; NNRTI: non-nucleoside reverse transcriptase inhibitors; PI: protease inhibitor; TDF: tenofovir; FTC: emtricitabine; AZT: zidovudine; 3TC: lamivudine; ABC: abacavir; LPV: lopinavir; ATV: atazanavir; FAP: fosamprenavir.

\begin{tabular}{lr|rr|rr}
\hline & & \multicolumn{2}{|c|}{ n } & \multicolumn{2}{c}{$\%$} \\
\hline 2 NRTI & & $\mathbf{1 7 8}$ & & $\mathbf{4 2}$ & \\
& TDF/FTC & & 103 & & 24 \\
& AZT/3TC & & 31 & & 7 \\
& 3TC/ABC & & 20 & & 5 \\
PI & & $\mathbf{1 3 1}$ & & $\mathbf{3 1}$ & \\
& LPV & & 76 & & 18 \\
& ATV & & 39 & & 9 \\
PI + NRTI/NNRTI & FAP & & 15 & & 4 \\
& & $\mathbf{5 8}$ & & $\mathbf{1 4}$ & \\
& LPV & & 34 & & 8 \\
& ATV & & 15 & & 4 \\
Not specified & FAP & & 7 & & 2 \\
Other & & $\mathbf{2}$ & & $\mathbf{0}$ & \\
\hline
\end{tabular}


tients or $21.4 \%$ ), more than one reason reported per patient was possible. Details of other antiretroviral drugs used with $\mathrm{SQV} / \mathrm{r}$ in this analysis are shown in Table 3.

The majority of patients received $\mathrm{SQV} / \mathrm{r}$ either as part of a PI plus two NRTIs regimen, most commonly TDF and FTC, or as a double PI regimen, most commonly with LPV.

\section{DisCONTINUATIONS}

In total, $22 \%(94 / 426)$ of the patients withdrew from the study prior to week $48(3.3 \%$ by week $4 ; 4.2 \%$ week $4-12 ; 6.3 \%$ week $12-24 ; 4.0 \%$ week $24-36 ; 4.2 \%$ week 36-48). Reasons for discontinuations were: side effects $(5.5 \% ; \mathrm{n}=24)$, virological failure $(3.5 \% ; \mathrm{n}=$ $15)$, lost to follow up ( $4 \% ; n=18)$, lack of adherence $(3.5 \% ; \mathrm{n}=15)$, intercurrent disease $(1 \% ; \mathrm{n}=3)$ and death $(0.5 \% ; \mathrm{n}=2$; all classified as unrelated to SQV). Reasons discontinuations were not specified for 17 patients (4\%). Of the 15 patients who withdrew from study due to virological failure, resistance data prior to the switch to the SQV-based regimen were available for eight patients, and resistance against a median of $3(0 ; 6)$ protease inhibitors was documented. No resistance data were available for the remaining seven patients.

\section{SAFETY AND TOLERABILITY}

Based on the reports obtained in the analysis, there were 34 adverse events (AEs) assessed as grade 3 or 4 and considered to be, in the opinion of the treating physician, possibly or likely related to $S Q V / r$. The majority of events were diarrhea and gastrointestinal problems, as recorded in 18 patients $(4.2 \%)$ (Table 4). Treatment with antidiarrhea agents $(13.0 \%)$ reduced the incidence of AEs.

Table 4. Adverse events (AEs) related to SQV

\begin{tabular}{l|lr|l|l}
\hline & \multicolumn{1}{|l|}{$\begin{array}{c}\text { Number } \\
\text { of AEs }\end{array}$} & $\begin{array}{c}\text { Number } \\
\text { of patients }\end{array}$ & $\%$ \\
\hline All AEs & 43 & 25 & 5.9 \\
AEs Grade 3/4 & 34 & 18 & 4.2 \\
Diarrhoea & & 12 & & \\
Gastrointestinal system & \multicolumn{2}{|r|}{16} & & \\
\hline
\end{tabular}

There were no clinically relevant changes from baseline in liver enzyme or bilirubin levels at week 48. Median changes from baseline to week 48 in female patients were: ALT -3.0 U/L (IQR -10.0, 4.0; n $=55) ; \mathrm{AST}-2.0 \mathrm{U} / \mathrm{L}(\mathrm{IQR}-7.0,6.0 ; \mathrm{n}=47)$; GGT $5.0 \mathrm{U} / \mathrm{L}(\mathrm{IQR}-2,45.6 ; \mathrm{n}=54)$ (ITT, LOCF analysis). In male patients, median changes from baseline to week 48 were: ALT $0.0 \mathrm{U} / \mathrm{L}$ (IQR -8.0, 6.0; $\mathrm{n}=$ 335); AST 0.0 U/L (IQR -6.0, 5.0; n = 301); GGT $8.15 \mathrm{U} / \mathrm{L}$ (IQR $-0.55,393 ; \mathrm{n}=332$ ) (ITT, LOCF analysis). Median change in bilirubin levels from baseline to week 48 was $0.0 \mathrm{mg} / \mathrm{dl}$ (IQR $-0.2,0.25 ; \mathrm{n}=$ 258).
Virological AND ImMUNOLOGICAL RESPONSE

Median increase in CD4 count was +61 cells $/ \mathrm{mm}^{3}$ (IQR -9; 170; $\mathrm{p}<0.01$ ) from baseline to week 48 (Fig. 3). The proportion of patients achieving HIV RNA levels of $<50$ copies $/ \mathrm{mL}$ by 48 weeks was $60.3 \%$ (compared with $31.7 \%$ at baseline) and $74.9 \%$ (compared with $44.8 \%$ at baseline) for $<400$ copies $/ \mathrm{mL}$ (ITT, LOCF analysis), respectively (Fig. 3).

In patients who switched to SQV because of toxicity to another PI, HIV-RNA and CD4 levels remained stable. For those patients who switched to SQV because of virological failure, there was a marked improvement in these parameters.

\section{Changes in Lipid Profiles}

There was no significant change in overall triglyceride levels between baseline and week 48 in our patient cohort ( $p=0.81$; McNemar/Bowker testing). However when stratified according to baseline triglyceride levels, patients with baseline triglyceride above 200-750 $\mathrm{mg} / \mathrm{dL}$ and, most markedly, those above $750 \mathrm{mg} / \mathrm{dL}$ showed significant decreases in levels (Figs. 1a and 1b). Median changes in triglyceride levels stratified according to baseline levels were $+14 \mathrm{mg} / \mathrm{dL}$ (IQR -8; 57) for patients with baseline $<200 \mathrm{mg} / \mathrm{dL}(\mathrm{p}<0.01 ; \mathrm{n}$ $=196),-50 \mathrm{mg} / \mathrm{dL}(\mathrm{IQR}-139 ; 0)$ for patients with baseline $200-750 \mathrm{mg} / \mathrm{dL}(\mathrm{p}<0.01 ; \mathrm{n}=136)$ and -656 $\mathrm{mg} / \mathrm{dL}(\mathrm{IQR}-1024 ; 0)$ for patients with baseline $>750$ $\mathrm{mg} / \mathrm{dL}(\mathrm{p}<0.01 ; \mathrm{n}=15)$ (IT'T, LOCF analysis).

In the overall cohort there was slight but significant shift towards higher total cholesterol (TC) levels between baseline and week 48 in the McNemar/Bowker test $(p=0.026)$. However, after patients had been stratified according to baseline TC levels, a modest increase in median TC levels of $+16 \mathrm{mg} / \mathrm{dL}$ (IQR -3 ; 43) for patients with baseline levels $<200 \mathrm{mg} / \mathrm{dL}$ $(\mathrm{p}<0.01 ; \mathrm{n}=206)$, a decrease of $-3 \mathrm{mg} / \mathrm{dL}$ (IQR -25 ; 25) for patients with baseline levels $200-300 \mathrm{mg} / \mathrm{dL}$ (p $=0.40 ; \mathrm{n}=121$ ) and a marked fall of $-47 \mathrm{mg} / \mathrm{dL}$ (IQR -87 ; -4) for patients with baseline levels $>300$ $\mathrm{mg} / \mathrm{dL}(\mathrm{p}<0.01 ; \mathrm{n}=11)$ (IT'T, LOCF analysis) was observed (Figs. 2 and $2 \mathrm{~b}$ ).

With regard to LDL levels, although in the cohort of patients as a whole there was a significant shift towards an increase in LDL levels between baseline and week 48 in the McNemar/Bowker test ( $p=0.01$ ), only patients with LDL $<130 \mathrm{mg} / \mathrm{dL}$ at baseline showed a small increase in LDL cholesterol at week 48 (+8 mg/dL [IQR -4; 27]; $\mathrm{p}<0.01 ; \mathrm{n}=146$ ) There was no overall change in levels for patients with LDL $130-190 \mathrm{mg} / \mathrm{dL}$ at baseline $(0 \mathrm{mg} / \mathrm{dL}$ [IQR -15; 14]; $\mathrm{p}=0.79 ; \mathrm{n}=66)$, while levels fell significantly in patients with $\mathrm{LDL}>190 \mathrm{mg} / \mathrm{dL}$ at baseline $(-41 \mathrm{mg} / \mathrm{dL}$ [IQR -49; 6]; $\mathrm{p}<0.05 ; \mathrm{n}=9$ ) (ITT, LOCF analysis) (Fig. 2a).

There was also a small, but non-significant increase in HDL levels between baseline and week 48 in the group of patients as a whole by the Bowker test ( $\mathrm{p}=$ 0.13) (data not shown). When stratified according to baseline, this was significant in patients with HDL $\geq$ $40 \mathrm{mg} / \mathrm{dl}$ at baseline (+ $5 \mathrm{mg} / \mathrm{dL}$ [IQR 0; 9]; $\mathrm{p}=0.01$; $\mathrm{n}=93)$. 


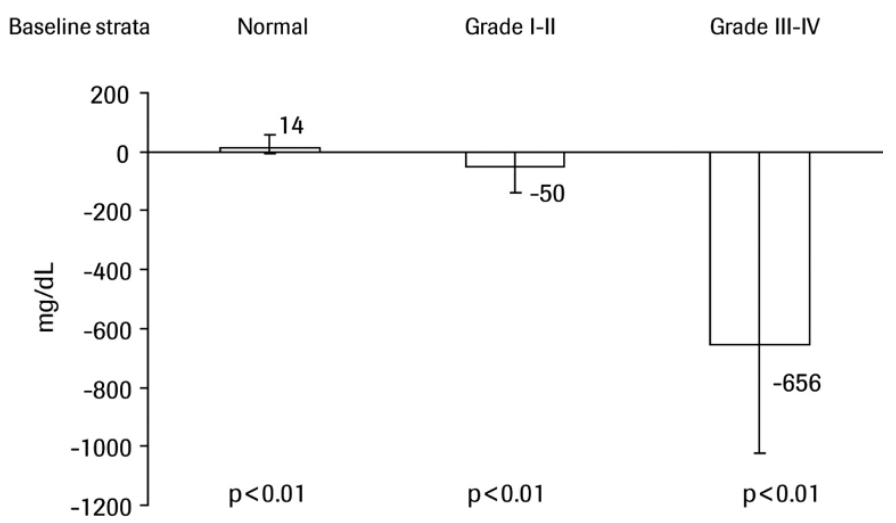

\begin{tabular}{|c|c|c|c|c|c|}
\hline \multicolumn{2}{|c|}{} & \multicolumn{3}{|c|}{ Week 48} & \\
\cline { 2 - 6 } \multicolumn{2}{|c|}{} & $\begin{array}{c}<200 \\
\mathrm{mg} / \mathrm{dL}\end{array}$ & $\begin{array}{c}200-750 \\
\mathrm{mg} / \mathrm{dL}\end{array}$ & $>750 \mathrm{mg} / \mathrm{d}$ & Total \\
\hline \multirow{3}{*}{ Baseline } & \begin{tabular}{c}
$200 \mathrm{mg} / \mathrm{dL}$ \\
\cline { 2 - 6 }
\end{tabular} & 151 & 44 & 1 & 196 \\
\cline { 2 - 7 } & $\begin{array}{c}200-750 \\
\mathrm{mg} / \mathrm{dL}\end{array}$ & 45 & 85 & 6 & 136 \\
\cline { 2 - 7 } & $\begin{array}{c}>750 \mathrm{mg} / \mathrm{dL} \\
\end{array}$ & 2 & 9 & 4 & 15 \\
\hline & Total & 198 & 138 & 11 & 347 \\
\hline
\end{tabular}

McNemar/Bowker-Test: $p=0.8147$

b

a

Fig. 1. Change in triglyceride levels from baseline to week 48 (ITT, LOCF): (a) median change (IQR) of triglycerides from baseline to week 48, stratified according to baseline level; (b) changes in triglyceride levels stratified by Grade.

Baseline strata

Normal: <200 mg/dL; Grade I-II: 200-750 $\mathrm{mg} / \mathrm{dL}$; Grade III-IV: >750 mg/dL

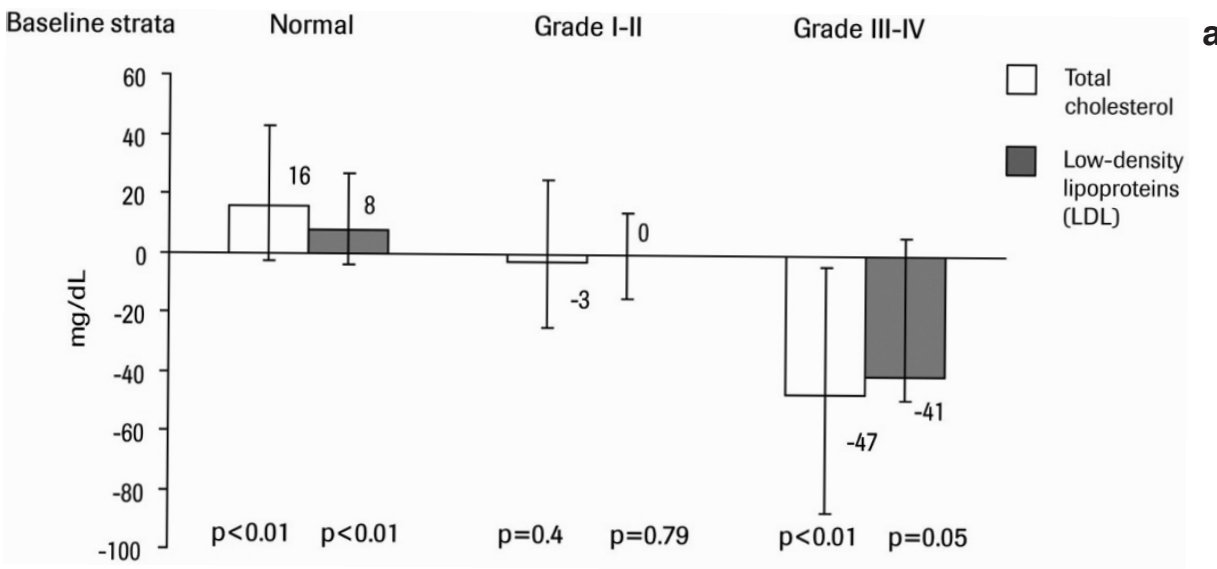

\begin{tabular}{|c|c|c|c|c|c|}
\hline \multicolumn{2}{|c|}{} & \multicolumn{3}{|c|}{ Week 48 } & \\
\cline { 2 - 6 } \multicolumn{2}{|c|}{} & $\begin{array}{r}<200 \\
\mathrm{mg} / \mathrm{dL}\end{array}$ & $\begin{array}{c}200-300 \\
\mathrm{mg} / \mathrm{dL}\end{array}$ & $\begin{array}{r}>300 \\
\mathrm{mg} / \mathrm{dL}\end{array}$ & Total \\
\hline \multirow{3}{*}{ Baseline } & \begin{tabular}{c}
$200 \mathrm{mg} / \mathrm{dL}$ \\
\cline { 2 - 6 }
\end{tabular} & 145 & 61 & 0 & 206 \\
\cline { 2 - 7 } & $>300 \mathrm{mg} / \mathrm{dL}$ & 0 & 8 & 3 & 11 \\
\cline { 2 - 7 } & $\begin{array}{c}200 \\
\mathrm{mg} / \mathrm{dL}\end{array}$ & 32 & 79 & 10 & 121 \\
\hline & Total & 177 & 148 & 13 & 338 \\
\hline
\end{tabular}

b

Fig. 2. Change in total cholesterol and LDL from baseline to week 48 (ITT, LOCF): (a) median change (IQR) in total cholesterol and LDL, stratified according to baseline level; (b) changes in total cholesterol stratified by Grade. Baseline strata

Normal: Total cholesterol $<200 \mathrm{mg} / \mathrm{dL}$; LDL $<130 \mathrm{mg} / \mathrm{dL}$

Grade I-II: Total cholesterol 200-300 mg/dL; LDL 130-190 mg/dL

Grade III-IV: Total cholesterol $>300 \mathrm{mg} / \mathrm{dL}$; $\mathrm{LDL}>190 \mathrm{mg} / \mathrm{dL}$ 
Fig. 3. Proportion of patients with HIV-1 RNA levels $<50$ copies $/ \mathrm{mL}$ and $<400$ copies/mL and change in $\mathrm{CD} 4+$ levels baseline to week 48 (ITT, LOCF).

The proportion of patients receiving lipid lowering agents remained stable throughout the study period (6.6 \% at baseline vs. $6.1 \%, 6.3 \%, 5.9 \%$ and $6.3 \%$ at weeks 12, 24, 36 and 48, respectively).

The following parameters did not affect outcome in terms of lipid levels: use of lipid-lowering agents; previous treatment with stavudine or efavirenz; previous therapy using double PIs; new use of SQV in double PI therapy.

\section{Discussion}

This analysis confirms that ritonavir-boosted SQV is effective and well-tolerated in PI-experienced but SQV-naïve patients in a real-life clinical setting. Our data demonstrate that switching to SQV was beneficial both for those patients who had intolerance or toxicity to their previous ART regimen, and those who failed previous treatment due to virological failure. The proportion of patients with HIV RNA levels $<50$ copies $/ \mathrm{mL}$ at 48 weeks was almost twice that seen at baseline, and a significant increase in CD4 cell count was also seen by 48 weeks. Interestingly, the increase in CD4 count reflected the virological response. Increases in CD 4 count and reductions in HIV-1 RNA levels were especially marked in those patients who switched to SQV because of previous virological failure. In PI-experienced patients with Grade 3/4 elevations in lipid levels at baseline, switching treatment to SQV was associated with significant and marked improvements in triglyceride, LDL cholesterol and TC levels. Overall, lipid level changes after 48 weeks of SQV-based ART were relatively small in those patients with normal baseline levels, but median levels were significantly improved in those patients with Grade $3 / 4$ levels at baseline. Of note, median triglyceride levels in PI-pretreated patients with Grade 3/4 levels showed a particularly marked decline. The favorable triglyceride, lipid and liver enzyme and bilirubin profiles confirm the tolerability of SQV $500 \mathrm{mg}$ film tablets in this group of patients.

The tolerability and efficacy of SQV/r 1000/100 $\mathrm{mg}$ bid has been demonstrated in the a number of trials, which incorporated a range of patient types including patients who switched to $\mathrm{SQV} / \mathrm{r}$ as a result of intolerance or virological failure $[8,12,18,19]$. These studies predominantly used the earlier $200 \mathrm{mg}$ hardcapsule or soft gel formulations of SQV. The $500 \mathrm{mg}$ film-coated formulation of SQV used in our study was introduced to address the problems of high pill burden and its potential effect on adherence [17]. As there are currently few data from studies using the new formulation in PI-experienced patients, we conducted the current analysis to investigate the safety and efficacy of the $500 \mathrm{mg}$ film-coated formulation of SQV in this patient population treated in a real-life clinical setting. Interestingly, results from our cohort of PI-experienced patients are similar to those seen in ART-naïve patients. In the open-label, non-inferiority GEMINI trial of first-line $\mathrm{SQV} / \mathrm{r}$ plus emtricitabine/tenefovir (FTC/TDF) vs. ritonavir-bosted lopinavir (LPV/r) plus FTC/TDF, $64.7 \%$ and $72.5 \%$ of patients in the $\mathrm{SQV} / \mathrm{r}$ arm achieved HIV-1 RNA levels $<50$ copies $/ \mathrm{mL}$ and $<400$ copies/mL, respectively [11], compared with $60.3 \%$ and $74.9 \%$, respectively, in the current analysis.

The incidence and nature of AEs were similar in our cohort of patients to those previously reported in clinical trials and were most commonly gastrointestinal and diarrhea $[8,9,11,18]$. There was no indication of relevant changes in liver enzymes or bilirubin in our patient cohort. Changes in lipid profile are of particular concern with PI-based ART, with treatment-related dyslipidemia being linked to atherogenesis and increased risk of coronary artery disease [1-4]. Treatment with $\mathrm{SQV} / \mathrm{r}$ has been found to be associated with a more favorable lipid profile than ritonavirboosted indinavir and lopinavir $[8,11]$. In the current analysis, switching to $\mathrm{SQV} / \mathrm{r}$ resulted in a marked decrease in levels of both triglycerides and total cholesterol in those patients who had increased baseline levels, most markedly in those with Grade III/IV levels at baseline. Furthermore, LDL cholesterol levels also declined in those patients with high baseline levels in our analysis. Despite a slight increase in median triglyceride-, total cholesterol- and LDL cholesterollevels in patients within the normal range at baseline, the whole proportion of patients within the normal range for these parameters was comparable high, preand post-SQV $/ \mathrm{r}$ therapy. Taken together, these finding suggest a favorable lipid profile of $\mathrm{SQV} / \mathrm{r}$ for PI-experienced patients. 
The main strength of the current analysis of patients from the RAINBOW survey lies in the fact that it consists of an unselected cohort of HIV-infected patients treated under routine, 'real-life' conditions in contrast to the highly selective and controlled randomised trial situation. The data derived from such cohorts may more closely reflect clinical practice than results obtained from the optimized setting of clinical studies. However the study has the usual limitations of observational analyses. It is not possible to rule out selection bias, although all RAINBOW investigators were encouraged to report data from all eligible patients at their site rather than reporting on a random subset only. In addition, the case-payment system used for data collection was based on completed visits per case, which may also have encouraged reporting.

This cohort study adds to the efficacy and safety data available for the new formulation of SQV used at the recommended treatment dose with ritonavir boosting by investigating its tolerability and effectiveness in PI-experienced patients. In addition it confirms the efficacy and tolerability of SQV seen in clinical trials in the 'real-world' clinical setting. Based on the findings of this analysis, SQV/r offers a viable option both for patients who have virological failure on previous PI-based therapy, or who suffer toxicity. In particular, in those patients with markedly elevated lipid levels following PI treatment, a switch to SQV/r was associated with a marked decline in triglyceride, total cholesterol and LDL cholesterol.

In conclusion, results from this observational cohort of PI-experienced patients treated with the currently approved dose of SQV/r and using the $500 \mathrm{mg}$ film-coated SQV formulation in the 'real life' clinical setting are consistent with high efficacy and tolerability seen in controlled studies with $\mathrm{SQV} / \mathrm{r}$.

Acknowledgements: The authors would like to thank all centers participating in German RAINBOW COHORT:

Bänsch U, Berlin; Baumann R, Neuss; Becker W, München; Bieniek B, Berlin; Bihari A-S, Köln; Brust J, Mannheim; Buhk T, Hamburg; Busch HW, Münster; Carganico A, Berlin; Carls H, Düsseldorf; Christensen S, Münster; Claus J, Berlin; Cordes C, Berlin; Fätkenheuer G, Köln; Fenske S, Hamburg; Fischer K, Berlin; Ghosh I, Berlin; Gläßel F, München; Glaunsinger T, Berlin; Gute P, Frankfurt/Main; Hartl H, München; Herrmann S, Köln; Hintsche B, Berlin; Holm S, Hannover; Hower M, Dortmund; Isernhagen K, Köln; Jägel-Guedes E, München; Jäger H, München; Jessen A, Berlin; Karwat M, München; Klauke S, Frankfurt/Main; Klinker H, Würzburg; Knecht G, Frankfurt/Main; Knechten H, Aachen; Köppe S, Berlin; Köthemann W, Köln; Kreckel P, Berlin; Lichtenstein Z, München; Locher L, Frankfurt/Main; Lutz T, Frankfurt/Main; Markus R, Frankfurt/Oder; Mauss S, Düsseldorf; Mayr C, Berlin; Meyer A, Hamburg; Miasnikov V, Düsseldorf; Moll A, Berlin; Mösch M, Frankfurt; Mosthaf FA, Karlsruhe; Müller M, Stuttgart; Mutz A, Osnabrück; Pfeil B, Leipzig; Prziwara D, Berlin; Rausch M, Berlin; Reith M, Düsseldorf; Römer K, Köln; Scheidegger C, München; Schewe KK, Hamburg; Schleehauf D, Berlin; Schlote F, Berlin; Schmidt, Hannover; Schnaitmann E, Stuttgart; Scholten S, Köln; Schuster D, Mannheim; Seidel T, Jena; Starke W, Wiesbaden; Staszewski S, Frankfurt; Stellbrink HJ, Hamburg; Stephan C, Frankfurt; Stoehr A, Hamburg; Strehlow A, Düsseldorf; Stücker W, Köln; Träder C, Berlin; Ulmer A, Stuttgart; Van Lunzen J, Hamburg; Volkert R, München; Waizmann M, Leipzig; Wünsche T, Berlin. The study was supported by Roche AG.

\section{REFERENCES}

1. Calza L, Manfredi R, Chiodo F. Dyslipidaemia associated with antiretroviral therapy in $\mathrm{HIV}$-infected patients. J Antimicrob Chemother. 2004 Jan; 53(1): 10-4. Review.

2. Koppel K, Bratt G, Eriksson M, Sandström E. Serum lipid levels associated with increased risk for cardiovascular disease is associated with highly active antiretroviral therapy (HAART) in HIV-1 infection. Int J STD AIDS. 2000 Jul; 11(7): 451-5.

3. DAD Study Group, Friis-Møller N, Reiss P, Sabin CA, Weber R, Monforte A, El-Sadr W, Thiébaut R, De Wit S, Kirk O, Fontas E, Law MG, Phillips A, Lundgren JD. Class of antiretroviral drugs and the risk of myocardial infarction. N Engl J Med. 2007 Apr 26; 356(17): 172335.

4. Walmsley S, Cheung AM, Fantus G, Gough K, Smaill F, Azad, Diong C, Raboud J. A prospective study of body fat redistribution, lipid, and glucose parameters in HIVinfected patients initiating combination antiretroviral therapy. HIV Clin Trials. 2008 Sep-Oct; 9(5): 314-23.

5. Palacios R, Merchante N, Macias J, González M, Castillo J, Ruiz J, Márquez M, Gómez-Mateos J, Pineda JA, Santos J. Incidence of and risk factors for insulin resistance in treatment-naïve $\mathrm{HIV}$-infected patients 48 weeks after starting highly active antiretroviral therapy. Antivir Ther. 2006; 11(4): 529-35.

6. Oldfield V, Plosker GL. Lopinavir/ritonavir: a review of its use in the management of HIV infection. Drugs. 2006; 66(9): 1275-1299.

7. Goldsmith D, Perry C. Atazanavir. Drugs 2003; 63(16): 1679-1693.

8. Dragsted UB, Gerstoft J, Pedersen C, Peters B, Duran A, Obel N, Castagna A, Cahn P, Clumeck N, Bruun JN, Benetucci J, Hill A, Cassetti I, Vernazza P, Youle M, Fox Z, Lundgren JD; MaxCmin1 Trial Group. Randomized trial to evaluate indinavir/ritonavir versus saquinavir/ritonavir in human immunodeficiency virus type 1-infected patients: the MaxCmin1 Trial. J Infect Dis. 2003 Sept 1; 188(5): 635-642.

9. Dragsted UB, Gerstoft J, Youle M, Fox Z, Losso M, Benetucci J, Jayaweera DT, Rieger A, Bruun JN, Castagna A, Gazzard B, Walmsley S, Hill A, Lundgren JD; MaxCmin2 Trial Group. A randomized trial to evaluate lopinavir/ritonavir versus saquinavir/ritonavir in HIV-1infected patients: the MaxCmin2 trial. Antivir Ther. 2005; 10(6): 735-743.

10. Ananworanich J, Gayet-Ageron A, Ruxrungtham K, Chetchotisakd P, Prasithsirikul W, Kiertiburanakul S, Munsakul W, Raksakulkarn P, Tansuphasawadikul S, LeBraz M, Jupimai T, Ubolyam S, Schutz M, Hirschel B; Staccato Thailand Study Group.. Long-term efficacy and safety of first-line therapy with once-daily saquinavir/ritonavir. Antivir Ther. 2008; 13(3): 375-380.

11. Walmsley S, Avihingsanon A, Slim J, Ward DJ, Ruxrungtham K, Brunetta J, Bredeek UF, Jayaweera D, Guittari CJ, Larson P, Schutz M, Raffi F. Gemini: A Noninferiority Study of Saquinavir/Ritonavir Versus Lopinavir/Ritonavir as Initial HIV-1 Therapy in Adults. J Acquir Immune Defic Syndr. 2009 Apr 1; 50(4): 367-374.

12. German and Austrian guidelines for the diagnosis and therapy of HIV-infection. 2008.

13. Hammer SM, Eron JJ Jr, Reiss P, Schooley RT, Thompson MA, Walmsley S, Cahn P, Fischl MA, Gatell JM, Hirsch MS, Jacobsen DM, Montaner JS, Richman DD, Yeni PG, Volberding PA; International AIDS SocietyUSA. Antiretroviral treatment of adult HIV infection: 2008 recommendations of the International AIDS Society-USA panel. JAMA. 2008 Aug 6; 300(5): 555-70.

14. European AIDS Clinical Society Guidelines 2008. http://www.eacs.eu/guide/index.htm . 
15. Salzberger B, Marcus U, Vielhaber B, Arasteh K, Gölz J, Brockmeyer NH, Rockstroh J. German-Austrian recommendations for the antiretroviral therapy of HIV-infection (status May 2004). Eur J Med Res. 2004 Nov 29; 9(11): 491-504.

16. Invirase ${ }^{\circledR}$ Summary of product characteristics. http:// emc.medicines.org.uk/document.aspx?documen $\mathrm{tId}=16123$.

17. Bittner B, Riek M, Holmes B, Grange S. Saquinavir 500 $\mathrm{mg}$ film-coated tablets demonstrate bioequivalence to saquinavir $200 \mathrm{mg}$ hard capsules when boosted with twice-daily ritonavir in healthy volunteers. Antivir Ther. 2005; 10(7): 803-810.

18. Valer L, De Mendoza C, De Requena DG, Labarga P, García-Henarejos A, Barreiro P, Guerrero F, Vergara A, Soriano V; Fortogene Spanish Study Group. Impact of HIV genotyping and drug levels on the response to salvage therapy with saquinavir/ritonavir. AIDS. 2002 Sep 27; 16(14): 1964-6.
19. de Mendoza C, Valer L, Ribera E, Barreiro P, Martín-Carbonero L, Ramirez G, Soriano V. Performance of six different ritonavir-boosted protease inhibitor-based regimens in heavily antiretroviral-experienced HIV-infected patients. HIV Clin Trials. 2006 Jul-Aug; 7(4):163-71.

Received: September 21, 2009 / Accepted: January 5, 2010

\section{Address for correspondence:}

C. Stephan

Klinikum der Johann-Wolfgang-Goethe-Universität

Theodor-Stern-Kai 7

60590 Frankfurt

Germany

Tel,: $\quad+496963017680$

Fax: $\quad$ +496963015712

E-mail: C.Stephan@em.uni-frankfurt.de 